\title{
Successful Anatomical Access for Surgical Removing of the Distal Fracture of Splint Bones in Thoroughbred Horses (Case Study)
}

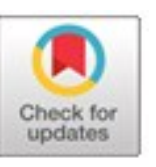

\author{
Mohamed H. Abushhiwa ${ }^{1 *}$, Osama Sawesi ${ }^{2}$, Khaled A. Milad ${ }^{2}$, Aiman. A. Shalgum ${ }^{3}$ \\ and Abdulrhman M. Alrtib ${ }^{3 *}$ \\ ${ }^{1}$ Department of Surgery and Theriogenology, Faculty of Veterinary Medicine, University of \\ Tripoli, Tripoli, Libya \\ ${ }^{2}$ Department of Internal Medicine, Faculty of Veterinary Medicine, University of Tripoli, \\ Tripoli, Libya \\ ${ }^{3}$ Department of Anatomy, Histology and Embryology, Faculty of Veterinary Medicine, \\ University of Tripoli, Tripoli, Libya
}

Received: 11 March 2019/ Accepted: 30 June 2019

Doi: https://doi.org/10.54172/mjsc.v34i2.80

\begin{abstract}
Poor performance in athletic horses due to musculoskeletal affections is very common in Libya. Two mature thoroughbred horses suffering from poor performance and history of moderate degree forelimb lameness were admitted to the Aswany Private Equine clinic in Tripoli, Libya. The study is aiming for presenting a simple, time effective, cost effective surgical procedure to treat distal simple splint bone fracture in thoroughbred horses. Horses were examined thoroughly for the common muscle, hoof, and tendons affections. A progressed unilateral left forelimb swelling involving the lateral distal part of the fourth metacarpal bones was noticed. Three radiographs were taken to each horse including lateromedial, dorsolateral-palmaromedial, and palmarolateral-dorsomedial views to assess both splint bones. The radiographs showed that there is a complete fracture involving the distal extremity (button) of the fourth metacarpal bones. Surgical excisions of the fractured part of the splint bones have been decided to treat these horses. To precisely locate the site of the bone fragments, $1.5 \mathrm{~mm}$ stainless steel wires were placed over the distal part of splint prior to taking the radiographs. The surgical sites were aseptically prepared, and the horses were then sedated via intravenous injection of xylazine at a dose rate of $1 \mathrm{mg} / \mathrm{kg}$ body weight. The site of surgical incision was infiltrated with $2 \%$ lidocaine. The bone fragments were then removed after performing the surgical incision. The sharp end at the distal end of the proximal part of the splint bone was then smoothening with a scissor. The surgical incisions were then routinely closed and the post-operative care and radiographs were taken. The surgical incision made complete healing within two weeks. Both horses were followed up for up to three years post-operation, and they did well compared to what has been done in other studies. We concluded that the surgical technique used to treat the two horses with splint bone fracture enrolled in the current study is a simple and effective procedure.
\end{abstract}

Keywords: forelimb lameness, distal splint bone fracture, surgical ostectomy,

\section{INTRODUCTION}

Fracture of the second and fourth metacarpal bones (splint bones) is relatively common in thoroughbred horses and can occur at any age
(K. Bowman, L. Evans, \& M. E. Herring, 1982; F. Verschooten, Gasthuys, \& De Moor, 1984). The most common site of this fracture is the distal part of the splint bone $(\mathrm{K}$.

*Corresponding Author: Mohamed H. Abushhiwa mashames1976@gmail.com, Department of Surgery and Theriogenology, Faculty of Veterinary Medicine, University of Tripoli, Tripoli, Libya 
Bowman et al., 1982; Jenson, Gaughan, Lillich, \& Bryant, 2004; F. Verschooten et al., 1984). Additionally, splint bone fracture involving the distal part of the bone is mostly simple (Baxter 2011). Furthermore, it has been reported that distal splint bone fracture occurs mainly in horses aged between 5 to 7 years, which is proposed due to the decrease pliability of the suspensory ligament. This type of fracture occurs more frequently in forelimbs than hindlimbs and occurs mainly in the lateral splint bone of the left forelimb (Baxter, 2011).

It has been found that the distal splint bone fracture occurs either due to internal trauma resulting from excessive pulling of the bone with carpal extension by suspensory ligament and its fascial attachments during exercise, particularly in forelimb or external direct trauma (K. F. Bowman, L. H. Evans, \& M. E. Herring, 1982; F Verschooten, Gasthuys, \& Moor, 1984). Additionally, distal splint bone fracture can occur because of interosseous ligament desmitis and decreasing of its pliability (Auer, 2012).

Distal splint bone fracture is usually characterized by local pain, swelling around the distal end of splint bone and heat in acute cases. Additionally, lameness may be observed in the acute stage of affection. However, all these findings are usually either not obvious or disappear in chronic cases (Baxter, 2011). Lameness may or may not be observed during trot or fast circling depending on the acuteness of the fracture (Baxter, 2011). In some chronic cases, the fracture site may create callus and cause hard swelling, which may confuse the veterinarian with other affections known as splints (Auer, 2012). The best diagnostic tool used to confirm the lesion is the radiography. Dorsolateral-palmaromedial and palmarolateral-dorsomedial views are required to confirm these fractures in the second or fourth metacarpal bones (Butler,
Colles, Dyson, Kold, \& Poulos, 2017).

Distal splint bone fracture associated with lameness is usually required intervention using distal splint bone osteotomy (Auer, 2012; K. F. Bowman et al., 1982; Jenson et al., 2004; F Verschooten et al., 1984).

\section{MATERIALS AND METHODS}

\section{Case history and signalmen:}

Two thoroughbred horses were admitted to Aswany Private Equine Clinic in Tripoli, Libya with a history of moderate lameness and localized pain and swelling around the distal end of the fourth splint bone. The horses were subjected to courses of antiinflammatory without any obvious improvement. The first case was a 5 years old, male TB racing horse suffering from left forelimb lameness and localized swelling just in the dorsal to the palmaro-lateral aspect of the fetlock. The second case was a 7-years old, TB racing horse with similar clinical signs to the former case.

\section{Radiographic examination:}

Two views were taken to each horse, namely dorsolateral-palmaromedial oblique view, and palmarolateral-dorsomedial oblique view (Figure $1 \mathrm{~A}$ and B). One stainless steel wire was placed over the swollen area and a number of short wires were then attached to the main wire in an attempt to localize the exact location of the fracture site (Figure 2A).

\section{Surgical procedure:}

The surgical sites were aseptically prepared. A dose of $1 \mathrm{mg} / \mathrm{kg}$ xylazine (Adwia, Egypt) was injected intravenously. The incision site was desensitized by local infiltration of $2 \%$ lidocaine hydrochloride (Vetquinol, Belgium). The incision is made over the distal part of lateral splint bone and the bone fragment was separated from the attached muscles and removed. The incision is routinely closed using absorbable and non- 
absorbable sutures. The follow up includes systemic antibiotic, local wound dressing, and complete rest for two week. The two cases were followed up for approximately three years via phone calls.

\section{RESULTS}

Clinical examinations of both horses revealed moderate degree of left forelimb lameness with localized painful swelling proximal to the fetlock on the palmar aspect at the distal end of the left-fourth metacarpal bones.

The radiographs show that there is a complete non-displaced fracture involving the distal of fourth metacarpal bones (Figures $1 \mathrm{~A}$ and $\mathrm{B}$ ). The surgical wounds made full recovery after two weeks with no complications. The follow-up radiographs at few months post-surgery showed that there is no bony reaction of the excision site (Figure 1 E). Additionally, follow up via phone conversation with the owners revealed that both horses were back to normal work after 2 months, and they did well with no lameness or swelling.

\section{DISCUSSION AND CONCLUSION}

The results of the current study correlated well with the previously published data. Both horses have no history of trauma, which indicates that both fractures are not traumatic. This finding agrees with that mentioned in the literature regarding the cause of this type of fracture (Auer, 2012; K. F. Bowman et al., 1982; F Verschooten et al., 1984). Distal splint bone fracture may associate with a moderate degree of lameness (Auer, 2012; K. F. Bowman et al., 1982; Jenson et al., 2004; F Verschooten et al., 1984), which is what we found in this study where the two horses suffered from lameness. It has been reviewed that the best treatment for distal splint bone fracture is the surgical excision (Auer, 2012). Our findings support this conclusion as both horses did well postsurgery without any complication. Additionally, the most interesting finding of the current study is that the surgical procedure for both operations was performed under sedation and local anesthesia without any difficulties. This surgical approach has many advantages as it avoids the surgeons the risks and cost of general anesthesia in equine. 


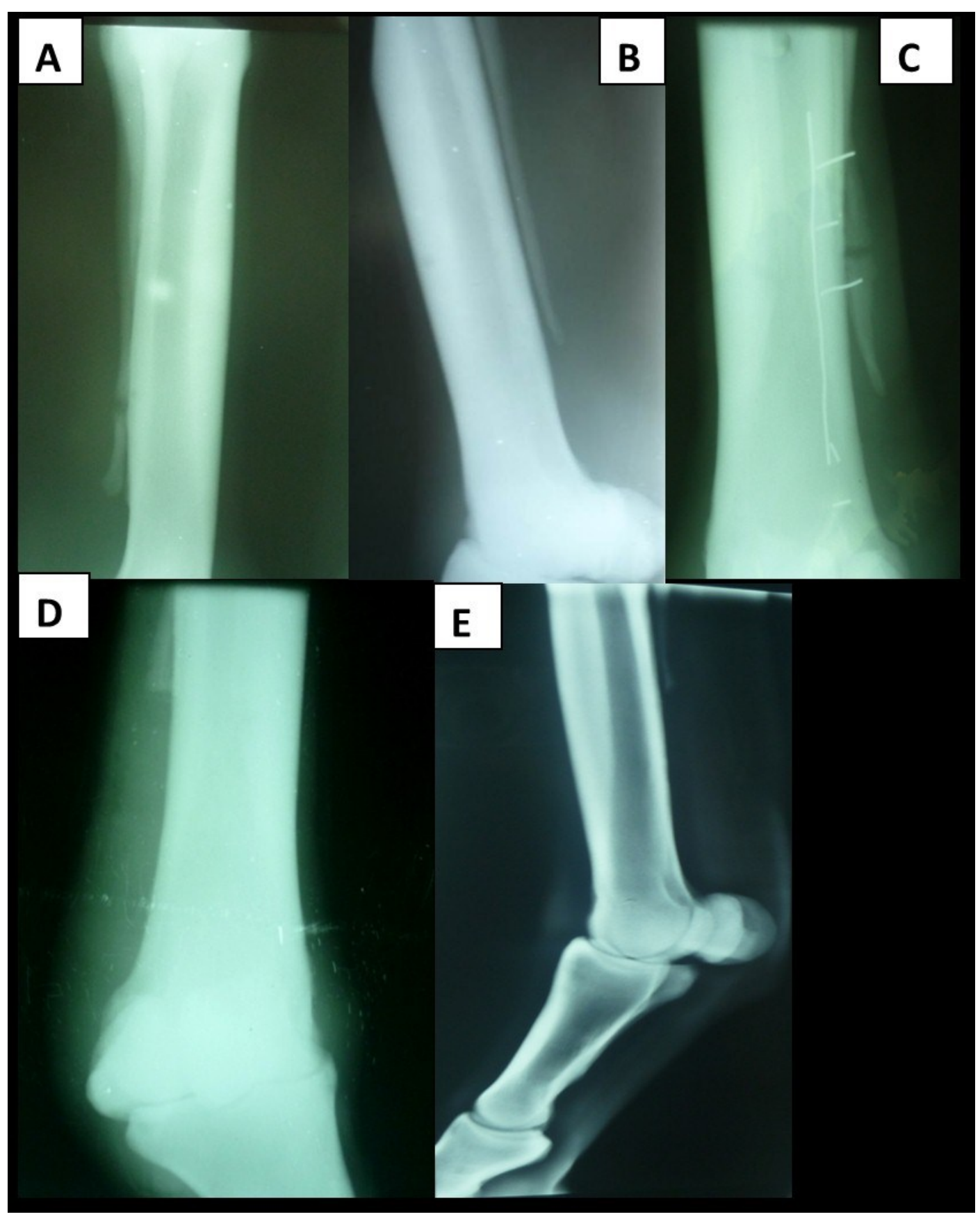

Figure (1). A. Dorsolateral - palmaromedial oblique view of the metacarpal region shows that there is a slightly displaced fracture on the distal fourth of the fourth splint bone. B. Dorsomedial - palmarolateral oblique view of the same horse shows a normal second splint bone. C. Dorsomedial - palmarolateral oblique view shows the stainless steel wire over the distal third of MC3 fracture site to precisely locate the bone fragment prior to surgery. D. Dorsomedial palmarolateral oblique view post-surgery shows the fractured splint bone after the surgical removal of the bone fragment. E. Dorsomedial - palmarolateral oblique view acquired 3 months post-surgery shows that there is no bony reaction at the osteoectomy site. 


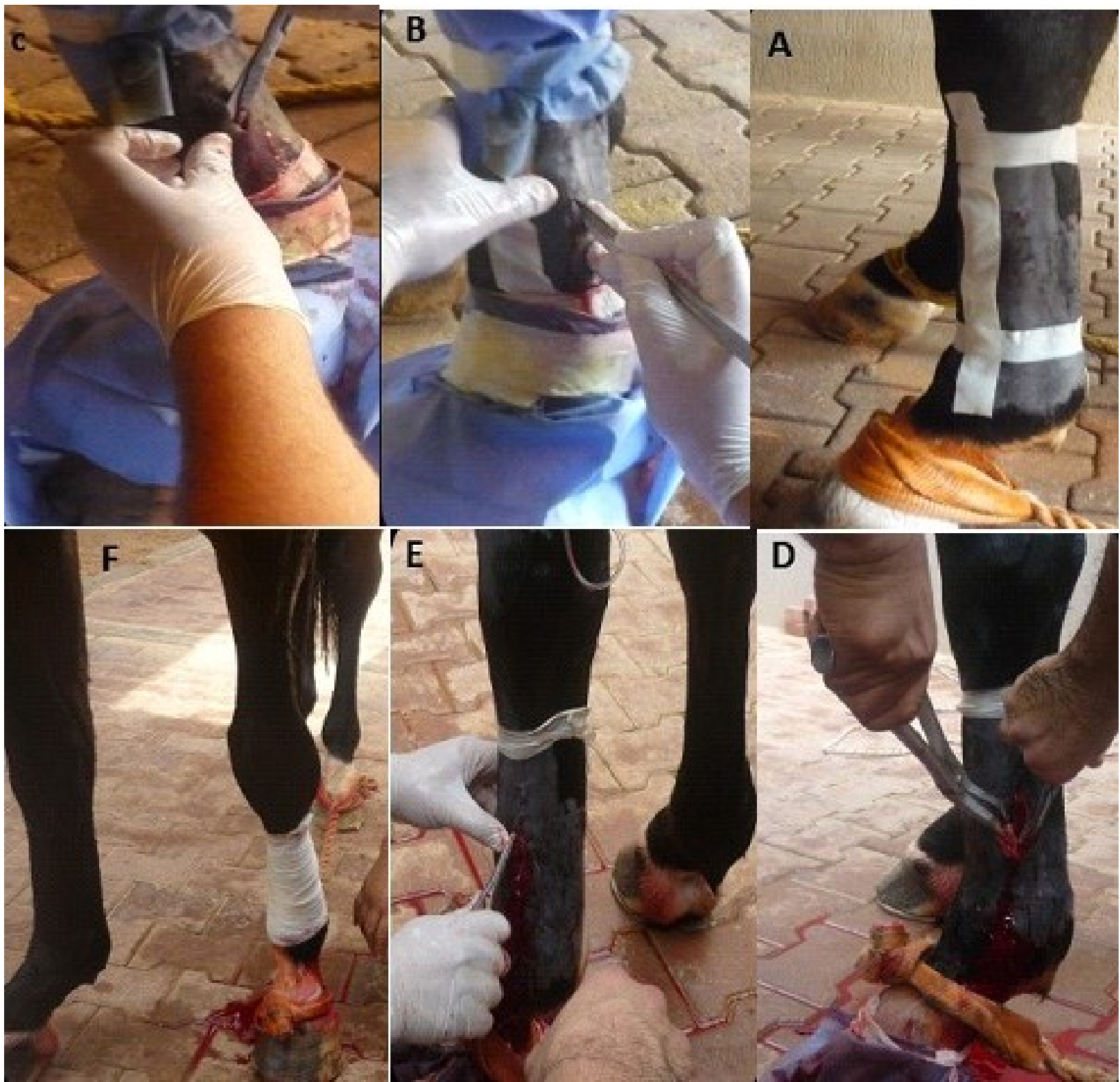

Figure (2): Illustrates the preparation of the surgical site prior to surgery and the surgical excision of fractured splint bone in thoroughbred horses. A. Preparation of surgical side and placing the stainless steel wire above the distal half of splint bone to precisely locate the site of the bone fragment. B. Shows the surgical incision. C. Shows the procedure of blind dissection in order to loose the under skin tissues. D. Shows the removal of the bone fragment after detaching it from the surrounding tissues. E. Shows the suturing of the surgical wound. F. Shows the dressing and bandaging

\section{REFERENCES:}

Auer, J. A. (2012). Principles of fracture treatment Equine Surgery (Fourth Edition) (pp. 1047-1081): Elsevier.
Baxter, G. M. (2011). Adams and Stashak's lameness in horses: John Wiley \& Sons.

Bowman, K., Evans, L., \& Herring, M. E. (1982). Evaluation of surgical removal of fractured distal splint bones in the 
horse. Veterinary Surgery, 11(4), 116120.

Bowman, K. F., Evans, L. H., \& Herring, M. E. (1982). Evaluation of Surgical Removal of Fractured Distal Splint Bones in the Horse. Veterinary Surgery, 11(4), 116120. doi: doi:10.1111/j.1532950X.1982.tb00682.x

Butler, J. A., Colles, C. M., Dyson, S. J., Kold, S. E., \& Poulos, P. W. (2017). Clinical radiology of the horse: John Wiley \& Sons.

Jenson, P. W., Gaughan, E. M., Lillich, J. D., \& Bryant, J. E. (2004). Segmental ostectomy of the second and fourth metacarpal and metatarsal bones in horses: 17 cases (1993-2002). J Am Vet Med Assoc, 224(2), 271-274.

Verschooten, F., Gasthuys, F., \& De Moor, A. (1984). Distal splint bone fractures in the horse: an experimental and clinical study. Equine Vet J, 16(6), 532-536.

Verschooten, F., Gasthuys, F., \& Moor, A. d. (1984). Distal splint bone fractures in the horse: an experimental and clinical study. Equine veterinary journal, 16(6), 532-536. 


\title{
الوصول التشريحي الناجح للإزالة الجراحية لكسر عظم المشط الرابع في الخيول الأصيلة
}

\author{
محمد الحمرونى أبوشهيوة1** أسامة خليفة سويسى²، خالد الكوني ميلاد²، أيمن عبد القادر شلغوم33 \\ وعبد الرحمن محمد الرطيب 3 \\ 1 قسم الجراحة والتتاسلبات، كلبة الطب البيطري، جامعة طرابلس، طرابلس، لبييا

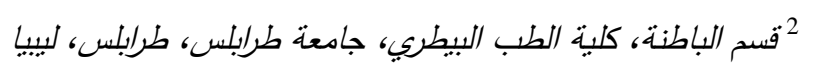

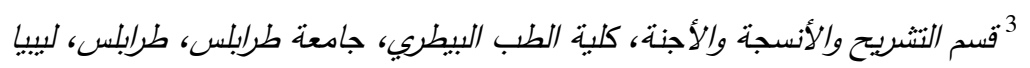

تاريخ الاستلام: 11 مارس 2019 / تاريخ القبول: 30 يونيو 2019 https://doi.org/10.54172/mjsc.v34i2.80:Doi

المستخلص: الأداء السيئ للخيول الرياضية بسبب إصابة العضات الهيكلية هو أمر شائع جدا في ليبيا. تم إدخال عدد اثثين من خيول السباق البالغة إلى عيادة السواني الخاصـة بالخيول في طرابلس، ليبيا، حيث كانت تعاني من سوء الأداء وعرج في القوائم

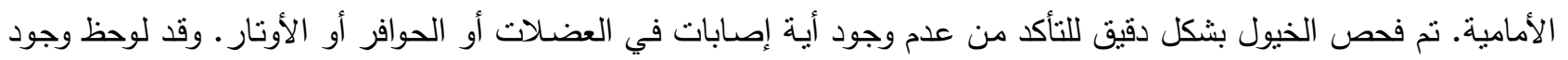
انتفاخ في النهاية السفلى لعظمة المشط الرابعة في القائمة الأمامية اليسرى. نم أخذ ثلاث صور إثنعاعية لكل حصان وذلك لتقبيه عظام المشط. أظهرت الصور الإشعاعية أن هناك كسورا كاملة في النهاية السفلى لعظمة المشط الرابعة. وقد ثقرر إجراء عملية

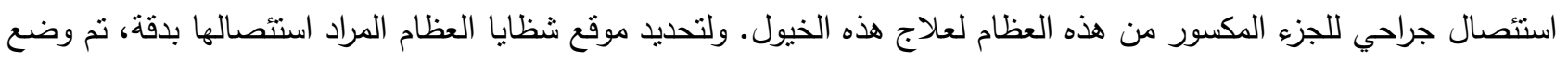
أسلاكى بقطر 1.5 ملم على الجزء السفلي لعظمة المشط الرابعة قبل التصوير الإشعاعي. تم تجهيز وتعقيم موقع العملية الجراحية ومن ثم تخدير الخيول باستخدام الحقن الوريدي لمادة الزيلازين بمعدل 1 مليجرام لكل كيلوجرام من وزن الجسم، وبعد ذلك تم تم حقن مكان الثق الجراحي بمادة الليدوكائين بتركيز 2 ٪. وبعد إجراء الثق الجراحي تم إزالة شظايا العظام المكسورة وتتعيم النهايات الحادة باستخدام المقص. أُخذت بعض الصور الإشعاعية للعظم المكسور بعد خياطة الثق الجراحي بشكل روتيني ومن ثم إحالة الخيول للرعاية الصحية. بعد أسبوعين من العملية التئام الجرح بشكل كامل. تمت منابعة الخيول لمدة ثناتث سنوات بعد العملية والتي تعافت بشكل جيد.

الكلمات المفتاحية: عرج الأرجل الأمامية، كسر عظمة المشط الرابعة، الإزالة الجراحية لكسر عظمة المشط الرابعة. 